\title{
Management of Achatina fulica (Bowdich, 1822) (Pulmonata: Achatinidae) in lettuce (Lactuca sativa L.)
}

\author{
Manejo de Achatina fulica (Bowdich, 1822) (Pulmonata: Achatinidae) \\ em alface (Lactuca sativa L.)
}

\author{
Lindinalva Santos ${ }^{1}$, Carla Barbosa Negrisoli² (D), Maciel Bispo Santos ${ }^{1}$, Aldomario Negrisoli Junior ${ }^{3 *}$ (iD

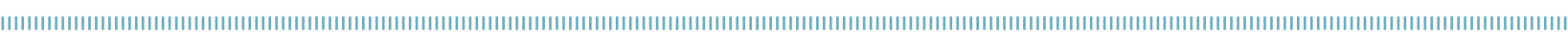

\begin{abstract}
The giant African snail Achatina fulica was introduced in Brazil and since then has become an important pest, because of its resistance to abiotic conditions, hermaphroditism, polyphagia, and absence of natural predators. This study aims to evaluate the control of $A$. fulica in lettuce, in Alagoas, Brazil. Bioassays for the determination of lethal dose and lethal time to adults of $A$. fulica and the egg mortality were performed in the laboratory by applying commercial synthetic products, commercial and non-commercial alcoholic botanical extracts on mollusk adults. Additionally, the protein concentration, lipase activity and enzyme acetylcholinesterase (AChE), and butyrylcholinesterase $(\mathrm{BuChE})$, in the stomach, intestine, nervous ganglion and liver were determined. The alcoholic extract of Capsicum frutescens caused higher mortality of $A$. fulica, and the alcoholic extract of C. frutescens and Piper tuberculatum oil can prevent the hatching of $A$. fulica. The lipase activity was present and in greater quantities in tissues, stomach, intestine, liver and ganglia of $A$. fulica, before and after exposure of the alcoholic extract of $C$. frutescens. The enzymatic activity of BuChE was present in the ganglia and liver of $A$. fulica, prior to exposure of the alcoholic extract of $C$. frutescens. The enzymatic activity of AChE was present only in the ganglion and absent in liver of $A$. fulica, prior to exposure of the alcoholic extract of $C$. frutescens. The concentration of $10 \%$ of the alcoholic extract of $C$. frutescens caused $84 \%$ mortality of adult $A$. fulica in lettuce in field conditions.
\end{abstract}

KEYWORDS: pesticides; botanical extracts; biological control; protein enzymes.
RESUMO: O caramujo-gigante-africano (Achatina fulica) foi introduzido no Brasil e desde entáo se tornou uma importante praga em virtude de sua resistência a condiçôes abióticas, hermafroditismo, polifagia e ausência de predadores naturais. Este estudo visa avaliar o controle de $A$. fulica em alface no estado de Alagoas, Brasil. Bioensaios para a determinaçấo da dose e de tempo letais para adultos de $A$. fulica e a mortalidade de ovos foram realizados em laboratório com a aplicaçáo de produtos sintéticos comerciais, extratos botânicos alcoólicos comerciais e não comerciais sobre caramujos adultos. Adicionalmente, determinaram-se a concentração proteica, a atividade lipásica e as enzimas acetilcolinesterase e butirilcolinesterase, no estômago, intestino, gânglio nervoso e fígado. O extrato alcoólico de Capsicum frutescens causou maior mortalidade de $A$. fulica, e o extrato alcoólico de $C$. frutescens e Piper tuberculatum mostrou que pode prevenir a eclosão de $A$. fulica. A atividade lipase estava presente e em maior quantidade nos tecidos, estômago, intestino, fígado e gânglios de $A$. fulica, antes e depois da exposição do extrato alcoólico de $C$. frutescens. A atividade enzimática da butirilcolinesterase estava presente nos gânglios e fígado, antes da exposição do extrato alcoólico de C. frutescens. A atividade enzimática de acetilcolinesterase estava presente apenas no gânglio e ausente no fígado de $A$. fulica, antes da exposição do extrato alcoólico de $C$. frutescens. A concentração de $10 \%$ do extrato alcoólico de $C$. frutescens causou $84 \%$ de mortalidade de adultos de $A$. Fulica em alface em condiçóes de campo.

PALAVRAS-CHAVE: pesticidas; extratos botânicos; controle biológico; enzimas proteicas. 


\section{INTRODUCTION}

Lettuce (Lactuca sativa L., Cichorieae) is the most consumed vegetables in Brazil and in the world (SANTOS et al., 2001), being present in the domestic market. Having economic importance in Brazil (BEZERRA NETO et al., 2005; LOPES et al., 2005), it accounts for $11 \%$ of production, with 4,908,772 tons (EMBRAPA HORTALIÇAS, 2013). Lettuce is normally produced in "green belts", near to consumer centers (SALA; COSTA, 2012), as the city of Arapiraca (Alagoas state, Brazil), that contributes to the improvement and expansion of public policy for horticulture (SILVA et al., 2013) and it is considered as the largest producer in the Alagoas state, providing lettuce to states of Pernambuco, Sergipe and Bahia (MONTEIRO, 2008).

Inclement weather, as well as arthropods, microorganisms and other unwanted agents, can adversely affect physical and organoleptic quality of vegetables (EMBRAPA HORTALIÇAS, 2015). In this sense, the giant African snail Achatina fulica (ESTON et al., 2006) (Pulmonata: Achatinidae), introduced in Brazil in 1988 (TELES; FONTES, 2002), has caused invasions and is present in all Brazilian states (THIENGO et al., 2007; THOMAZINI, 2008; OLIVEIRA et al., 2012, MADELLA; AURICCHIO, 2014).

The potential of $A$. fulica is favored by protandric hermaphroditism. I.e., young snails have only the male reproductive system and adults have both gonads, performing mutual copulation, fertilized with both individuals (TOMIYAMA; MIYASHITA, 1992). Each individual is able to lay a great number of eggs (around 400 eggs per clutch) (FISCHER; COLLEY, 2005), with low energy allocation (TOMIYAMA, 1994). The adult carries out an average of five or six ovipositions a year, and sperm can be stored for more than 120 days, allowing incubation for dry periods (aestivation), with laying eggs, so the weather conditions were favorable (RAUT; CHOSE, 1980). The sperm storage capacity provides species of Achatinidae ability to produce eggs in any season. After fertilization, the eggs in shell are kept internally and disposed at an advanced stage of embryonic development (RAUT; CHOSE, 1978).

The mature adult is approximately four months and has longevity of three to five years. The young molluscs present dispersion every six months, while adults are considered more sedentary (TOMIYAMA; NAKANE, 1993), foraging during the daytime and resting at night (TOMIYAMA, 1992). These gastropods, as well as other terrestrial molluscs, come into estivation for several months, during adverse weather periods, and tend to burrow into the soil (SIMONE, 1999) and form a protective layer, the epifragma, in order to temporarily close the opening of the shell, increasing the chance of survival (RAUT; CHOSE, 1981). Even species living in rainforests may stow during the driest months (RAUT; BARKER, 2002).
Considered as generalist herbivorous, A. Fulica can feed up to at least 500 species of crop plants of commercial interest (TELES et al., 2004) as: banana (Musa paradisiaca), beets (Beta vulgaris), calendula (Tagetes patula), cabbage and cauliflower (Brassica oleracea), Abelmoschus esculentus (L.) (Moench), pumpkin (Cucurbita pepo), papaya (Carica papaya), cucumber (Cucumis sativus), and others (VENETTE; LARSON, 2004). This mollusk is subject of intensive research, as evidenced in studies on metabolism and histology of the digestive gland (TUNHOLI-ALVES et al., 2015) and toxicity of triclosan (WANG et al., 2014), since their cutaneous secretion (mucus) is used in the development of biopharmaceuticals (LORENZI; MARTINS, 2008) and in zootherapy (FISCHER; ZANATTA; ADAMI, 2016).

The digestive tract of $A$. fulica consists of a large pharyngeal muscle, provided with a chitinous radula, esophagus, stomach, intestine and large intestine (rectum) (ZAITSEVA et al., 2009). The stomach is connected by ducts with liver occupying most of the visceral sac (ZAITSEVA et al., 2009), and possess an alveolar liver, which is the main organ of digestion and absorption of food. Activity of hydrolytic enzymes in the digestive juice of Helix spp. was extensively characterized by biochemical assay (MONRO et al., 1967), besides the intracellular protease activity reported in the midgut epithelium of this mollusc (ROSEN, 1937). The enzymatic apparatus of this group was investigated by FLORKIN; LOZET (1949), with conflicting evidence on the production of certain classes of hydrolytic enzymes. Differences occur primarily in the amount and distribution of digestive enzymes (lipase, proteases, carbohydrases and esterases) and the associated cellular metabolism (alkaline and acid phosphatase) (MONRO et al., 1967).

In general, gastropods as $A$. fulica are feeded on vegetative tissue and, therefore, need to have a system that allows the enzymatic digestion of polysaccharides, such as cellulose and hemicellulose, major constituents of the cell walls plants (BACIC et al., 1988). The control in modulation behaviors in many organisms is exercised by chemical mediators (amines and peptides).

The establishment of AchE as a chemical mediator in the nerve-nerve and nerve-muscle synapses has been proposed in several groups of invertebrates (WALKER; HOLDEN-DYE, 1989). A neuromuscular junction is a common site of AchE recognized as excitatory neurotransmitter in these synapses in invertebrates (WALKER; HOLDEN-DYE, 1989). The functional role of $\mathrm{AChE}$ in invertebrates is well known, and its pharmacological action, as well as their antagonists and agonists, has been widely investigated. In addition, the knowledge of their effects on invertebrates is probably as known as the observations of their actions in vertebrates. The action of AchE varies the invertebrate lineages, and in gastropods acts as a chemical mediator in motor synapses and interneuronal (WALKER; HOLDEN-DYE, 1989; ELLIOTT; KEMENES, 1992). 
Currently, different types of cholinesterase (ChE) found in vertebrates and invertebrates were characterized prior to their use as environmental assessment tool (NUNES, 2011). TALESA et al. (2001) characterized the AChEs of Mytilus galloprovincialis (NUNES, 2011) (Pelecypoda: Filibranchia). The nature of the AChEs that exist in vertebrates and invertebrates are quite different (NUNES, 2011). Invertebrates usually display only one way of AChE (MASSOULIÉ; BON 1982). FOURNIER et al. (1989) showed that native forms present in the insect Drosophila melanogaster was characterized by non-covalent association of two subunits dimer resulting from the proteolysis of the precursor encoded by locus.

$\mathrm{AChE}$ has essential importance in terminating the nerve impulse. Therefore, the regulation depends on its synthesis, by means of a feedback mechanism, the activation of nerve cells for the propagation of an action potential (NUNES, 2011). SCHWEITZER (1993) showed that the AChE is located mainly in the postsynaptic cell when expressed constitutively nerve cells are at rest; however, activation (for depolarization) of the cells leads to the release of AChE molecule to the extracellular space. AChE was found in homogenized of Mytilus edulis L. (Pteriomorphia: Mytilidae) (BROWN et al., 2004), and the activity of AChE in the gills was significantly inhibited by exposure to the compound BW284c51, a specific inhibitor of AChE (NUNES, 2011).

$\mathrm{BChE}$, the other ChE present in most vertebrate, is primarily found in plasma and has an unclear function (JBILO et al., 1994), but BChE may be involved in regulation of cell proliferation and early stages of the neural differentiation (MACK; ROBITZKI, 2000). Besides the presence in the body fluids, BChE can exist in hematopoietic cells, liver, lung, heart, in cholinergic synapses in the central nervous system, tumors and development of embryonic tissues (MACK; ROBITZKI, 2000). Future studies conclude that inhibition of $\mathrm{BChE}$ can be a valuable tool to determine ecotoxicology caused by the human (anthropogenic) and natural chemicals (NUNES; WHITACRE, 2011).

In this context, a few control methods are described in the literature: physical, chemical and biological. The massive collection and destruction of snails and their eggs have been effective in Guam, Hawaii, Japan, Sri Lanka, Australia and United States of America (USA) (RAUT; BARKER, 2002). According to RAUT; BARKER (2002), this control strategy is effective on a small scale or in public campaigns and farmer groups. Therefore, it is recommended to collect and bury the snails in pits dug in the field every day and/or burned or buried and covered with lime (ESTON et al., 2006).

Chemical control is mainly applied in order to protect vegetable plants during the seedling stage (most vulnerable) by adding metaldehyde suspension with detergent in cardboard strips. The chemical molluscicides, as formulated baits, especially metaldehyde-based, are commercially available (Metarex SP, Lesmax and Helistop), with problems being neutralized by the action of rain (DUN, 1967; RAUT; BARKER, 2002). NAIR (1968) demonstrated the effectiveness of kaolinite powder suspensions $1 \%$ and 1 to $4 \%$ of metaldehyde, but according to PRASAD et al. (2004) the main toxic effect of metaldehyde is the stimulation of the mucous glands, causing excessive sliming, both for intake and absorption by the mollusk foot leading to death by dehydration. Sodium chloride is also an effective dehydrating agent, forming a barrier of 12 " in perimeter areas infested. During periods of rain or high humidity, the barriers with this product must be renewed frequently (PRASAD et al., 2004).

There are many species of tropical plants identified in the literature as having molluscicides substances, e.g., Asteraceae, Euphorbiaceae, Fabaceae, Phytolaccaceae, Sapindaceae and Solanaceae (GUSMAN et al., 2014). Among the substances toxic to molluscs, there are alkaloids, saponins (triterpenoids), glycoside of oleanolic acid, spirostane, sesquiterpenoids (ambrosina and varburganal), coumarins, furanocoumarins (calepensin), flavonoids (quercertin and chalcon), quinolizidinic, lactones diterpenics, phenolic derivatives and tannins (HENDERSON et al., 1987; SANTOS et al., 2009).

NASCIMENTO et al. (2000) tested three species of Euphorbiaceae (Euphorbia milii var. Splendens, E. tirucalli and E. cotinifolia) and observed that only E. milii showed high molluscicidal activity on Leptinaria unilamellata (D'Orbigny), gastropod mollusc considered a pest of vegetables. The mollusk commonly associated by the wide distribution and high morbidity in Brazil Biomphalaria glabrata (Say) was highly susceptible to ethanol extract of Capsicum baccatum $\mathrm{L}$. with high toxicity (BOMFIM et al., 2002), due to bioactive substances (capsaicin and dihydrocapsaicin) (ZEWDIE; BOSLAND, 2001). On the other hand, PEREIRA et al. (1978) observed elevated toxicity of the hexane extract on leaves of Euphorbia cotinifolia (2.5 and $5.0 \mathrm{ppm}$ ) on Biomphalaria glabrata with molluscicidal effect on adults, causing severe bleeding 24 hours and total mortality 48 hours after exposure. The use of thiamethoxam in control of A. fulica population is only recommended in conjunction with the control of insect-pests (ABOG et al., 2012).

Almost a century has taken place trying to exterminate A. fulica in several countries (FISCHER; COLLEY, 2004). Disastrous introductions of natural enemies and the toxic action and non-specific chemicals have led to manual scavenging as the more used method (FISCHER; COLLEY, 2004).

Finally, the biological control has been carried out by Rosy Wolf Snail, Euglandina rosea (Férussac, 1821) (Eupulmonata: Spiraxidae), largely in biological control programs, and there were many failures with devastating effect on many native species rather than pests (GERLACH, 2001). Some species of Coleoptera, of Carabidae family, Anthia hexastica (Gerstaecker), Carabus violaceus (L.), and Scophinorus striatopunctatus (Choudoir) were used as biocontrol agents of this mollusk (SALLAM; EL-WAKEIL, 2012). 
The introduction of the flatworm Platydemus manokwari (De Beauchamp, 1963) (Turbellaria: Rhynchodemidae), a non-native predator of $A$. fulica, caused adverse effect on fauna indigenous gastropods (SHERLEY, 2000). In Europe, the nematode parasite Phasmarhabditis hermaphrodita (Schneider) (Nematoda: Rhabditidae) is used as biological control, sold as organic molusticide (Nemaslug, Becker Underwood, United States) (RAE et al., 2007). Considered facultative slug parasite, its infectious form known as infective juveniles (IJs) look for the hosts, penetrate the mantle cavity by natural openness and develop in the adult form, reproducing and killing the hosts after 21 days (TAN; GREWAL, 2001). The nematode is mass produced in association with the bacteria Moraxella osloensis (Bovre, 1979) (Pseudomonadales: Moraxellaceae), that promotes increased virulence in the nematode (TAN; GREWAL, 2001).

It is believed that the introduction of alien species is a threat to natural mollusk population and causes public health problems and economic losses. In order to avoid it, studies such as fluctuation of pest in different cultures should be prioritised, as well as the occurrence of knowledge and distribution associating the site, biology and ecology for the characterization, conservation, recovery of species and protection of natural environments preventing the extinction of species native (MACHADO et al., 2008).

There is great concern especially by government agencies in knowing the extent of the problem in Brazil (FISCHER; COLLEY, 2005). Knowledge of the preferred habitats and population dynamics of $A$. fulica is one of the first steps to manage this pest; thus, allowing targeted action is taken (FISCHER; COLLEY, 2005). The observation of a new outbreak of pest requires quick and effective actions to control, since the establishment of a new population is difficult to be eradicated (BARÇANTE et al., 2005). The changes in the production of digestive enzymes of $A$. fulica occur with changing diets offer an approach to cellular mechanisms in biological adaptations in animals (PROSSER; VAN WEEL, 1958). Snails adults are notorious excavators and do not show much preference for certain foods (at least in nature), and are therefore defined as omnivores (VAN WEEL, 1959). Studies on the biological characteristics and adaptive capacity of $A$. fulica related to nutrition and physiological processes are required, including, for example, the amount of protein (lipase), $\mathrm{AChE}$ and BChe.

Thus, the aim of this study was to evaluate new strategies of the A. fulica control.

\section{MATERIALS AND METHODS}

\section{Collection and maintenance of Achatina fulica}

The study was carried out from the period of August 1, 2013 to May 28, 2014, in horticultural areas of the "green belt" of the city of Arapiraca (Alagoas, Brazil), in the regions of Balsamo (9०49'256” 036³5'779'S, 4 m), Batingas (9०48'152"

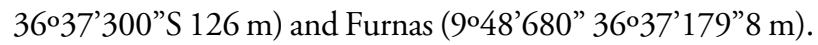
The type of crop system used was the conventional $(0.30$ between rows and $0.30 \mathrm{~m}$ between plants), without the application of pesticides or use of a control method of the snails.

The collections were conducted weekly, with the counting of the captured $A$. fulica adults and subsequent incineration of the specimens in each sampled site, preventing recounting. Part of the collected individuals was sent to the laboratory, and those that showed no symptoms of illness were created and used in laboratory bioassays. The A. fulica rearing was carried on plastic containers $(40 \times 30 \times 30 \mathrm{~cm})$ containing $1 \mathrm{~kg}$ of sterilized sand and feeded on carrot and potato peel, changed daily and cleaned every three days, besides being kept at $25 \pm 1^{\circ} \mathrm{C}$.

\section{Preparation of the alcoholic extract of Capsicum frutescens}

Fresh fruits of $C$. frutescens were taken to the laboratory for preparation and getting the alcoholic extract. Three hundred grams of fresh fruits were used, dried in an oven at $60^{\circ} \mathrm{C}$ and after 24 hours macerated to form a homogeneous powder.

The pepper powder was used as the base in preparing the alcoholic extract, which had as diluent medium ethanol $70 \%$, prepared at the following concentrations: $5 \%(\mathrm{v} / \mathrm{v}), 10 \%$ $(\mathrm{v} / \mathrm{v}), 15 \%(\mathrm{v} / \mathrm{v})$ and $20 \%(\mathrm{v} / \mathrm{v})$. After dilution of the proposed concentrations, the material remained at rest for 24 hours at $25 \pm 1{ }^{\circ} \mathrm{C}$ and was then filtered through fine mesh sieve and packed in plastic bottles for using in laboratory bioassays.

\section{Entomopathogenic nematodes, plant protection products and botanical extracts for control of adults Achatina fulica in the laboratory}

The entomopathogenic nematodes (EPNs) Steinernema glaseri RS38, Heterorhabditis bacteriophora RS58 and Heterorhabditis sp. AL42 were produced according to the technique mentioned by WOODRING; KAYA (1988), stored in $25 \mathrm{~mL}$ plastic containers and maintained at the temperature of $15 \pm 1{ }^{\circ} \mathrm{C}$, $70 \pm 10 \%$ relative humidity $(\mathrm{RH})$ and 12 hours photophase. Each EPN was micropipetted at the concentration of $1,000 \mathrm{IJs} / 5 \mathrm{~mL}$ aqueous suspension on adults of $A$. fulica in disposable containers of polyethylene $(20 \times 30 \times 15 \mathrm{~cm})$ containing two sheets of filter paper and lettuce (variety unknown) as food. Assessment of mortality of snails was made after seven days, time required for development of nematodes. The treatments were commercial insecticides (Evidence, Actara, Dipel, Cigaral), commercial botanical extracts (Rotenat CE, Compostonat and Natuneem), alcoholic botanical extract of 
C. frutescens (10\%) and control (water) in the dosages recommended by the manufacturers.

The experiment was completely randomized with 12 treatments and 10 repetitions, considering two snails by repetition. The percentage of mortality of adult snail was subjected to analysis of variance and comparison of means using the Tukey test $(\mathrm{p}<0.05)$.

\section{Evaluation of alcoholic extract and oil of Capsicum frutescens on freshly laid eggs of Achatina fulica and entomopathogenic nematodes}

Bioassays with eggs of $A$. fulica were carried out with four treatments: control, Heterorhabditis sp. AL39 (1,000 JIs/5 mL), oil $(5 \mathrm{~mL} / 5 \%)$, and alcoholic extract $(5 \mathrm{~mL})$ of $C$. frutescens and $P$. tuberculatum. In each plastic container $(30 \times 20 \times 15 \mathrm{~cm})$ two sheets of filter paper were added, to maintain humidity, on which 200 eggs of the pest were placed. The extracts and oils were applied using manual sprayers (200 mL capacity) and the nematode Heterorhabditis sp. AL39 using graduated pipettes. Daily, hatching rates of newly laid eggs were evaluated for a period of seven days.

The experiment was completely randomized with four treatments and ten repetitions, considering two snails by repetition. The percentage of mortality of $A$. fulica was subjected to analysis of variance and comparison of means using the Tukey test $(\mathrm{p}<0.05)$.

\section{Determination of concentration and lethal time of alcoholic extract of Capsicum frutescens on Achatina fulica in the laboratory}

The determination of concentration and lethal time was carried on plastic containers $(30 \times 20 \times 15 \mathrm{~cm})$ containing two sheets of filter paper, lettuce as food substrate and two young $(2 \mathrm{~cm})$ and adult $(10 \mathrm{~cm})$ snails per container, exposed at doses of 0 (control), 5, 10, 15 and 20\% alcoholic extract of C. frutescens, at $25 \pm 1{ }^{\circ} \mathrm{C}$.

The evaluation of the mortality rate of young and adults of the $A$. fulica was held on 24 and 48 hours after applying the treatment. The experiment was completely randomized with five treatments and 10 repetitions, considering two snails by repetition. The mortality data of snail adults were subjected to analysis of variance and comparison of means (Tukey $\mathrm{p}<0.05$ ).

\section{Preparation of protein extracts from tissues of adult Achatina fulica}

The tissues used of snail adults were ganglion, liver, stomach and intestines, washed with water to remove the debris stuck to the tissues. With the aid of forceps and scissors, the organs were extracted and, then, weighed and macerated in $2.5 \mathrm{~mL}$ of saline at the concentration of $0.9 \%$ (distilled water and sodium chloride) and homogenised. Then the mixture was shed into Eppendorf tubes $(2.5 \mathrm{~L})$ and taken in an ultrasonic bath (Ultraclean 700) for ten minutes to allow the breaking of the constituent cells of the tissues analyzed. Subsequently, the mixture was transferred onto glass wells, led to the centrifuge (HIMAC Hitachi) at 15,000 rpm for 15 minutes at $4{ }^{\circ} \mathrm{C}$. The supernatant was used for quantification of the protein concentration, lipase activity and $\mathrm{AChE}$, according to the methods of BRADFORD (1976), and CHOI et al. (2003).

Each aliquot of the supernatant was incubated with Bradford reagent (qs $1 \mathrm{~mL}$ ) for 5 minutes at room temperature and then measured by spectrophotometer (BRADFORD, 1976). Then, the spectrophotometer was reset with treatment blank (control) and after reading total protein values were obtained, to be launched in the Equation 1:

$\mathrm{A}=\mathrm{C} \times \mathrm{E} \times \mathrm{d}$

Where:

$\mathrm{A}=$ absorbance;

$\mathrm{C}=$ concentration;

$\mathrm{E}=$ molar extinction coefficient dinitrothiocyanobenzene (DNTB).

The aliquot of supernatant was incubated with 2,3-dimercapto-1-propanol tributyrate (DMPTB) reagent (qs $1 \mathrm{~mL}$ ) for 30 minutes in water bath at $37{ }^{\circ} \mathrm{C}$ and then read on a spectrophotometer length wavelength $(405 \mathrm{~nm})$ (CHOI et al., 2003). Free thiol groups that are generated by hydrolysis by lipases DMPTB reduced DNTB, which is yellow in color when reduced. Readings were taken in spectrophotometer model FlexStation 3 (Molecular Devices). This methodology was used as standard.

The experiment was completely randomized with two treatments and three replications. The average number of units or activities of the protein extract organs (liver and ganglia) of adult $A$. fulica was subjected to analysis of variance and comparison of means using the Tukey test $\mathrm{p}<0.05$.

\section{Efficiency of the alcoholic extract of Capsicum frutescens on adults of Achatina fulica on the field}

The experiment was installed on a particular area without using any agrochemical. The plots consisted of three lines per treatment, with the population of 207 plants of lettuce, distributed in 23 plants per row. The area was artificially infested by 90 adults of $A$. fulica, with distribution of 10 individuals per line. The snails were placed in cages $(20 \times 30 \mathrm{~cm})$, that were fixed on the plants using metal clips, in order to prevent the escape of 
these individuals. In treatments in which alcoholic suspension was applied, manual spray rib (10 L, model 428-01, Guarany) with Teejet flat fan nozzle (calibrated) in the concentrations 5 and $10 \%$ was used, which corresponds to 125 and $250 \mathrm{~g}$ of alcoholic extract, respectively. The evaluation was conducted two days after application with the removal of the cages containing the dead and the living snails, and the number of dead snails was counted.

The experiment was completely randomized, and the mortality rate of adult snail was subjected to analysis of variance and comparison of means using the Tukey test $(\mathrm{p}<0.05)$.

\section{RESULTS AND DISCUSSION}

\section{Entomopathogenic nematodes, plant protection products and botanical extracts for adults control Achatina fulica in the laboratory}

The alcoholic extract of $C$. frutescens to $5 \%$ caused the highest mortality of adults of $A$. fulica in the laboratory (47.32\%), statistically differing from the other treatments (Fig. 1). Evidences have been found about the toxic effect caused by $C$. frutescens (alkaloids as capsaicinoids) associated with caustic or spicy sensation, besides the presence of diterpenoids, flavonoids, phenolic compounds and saponins, with lethal action, anti-feed and water repellency to the invertebrates (RIBEIRO et al., 2008; MADHUMATHY et al., 2007). There was no statistical difference between the control and treatments: Cigaral, Actara,

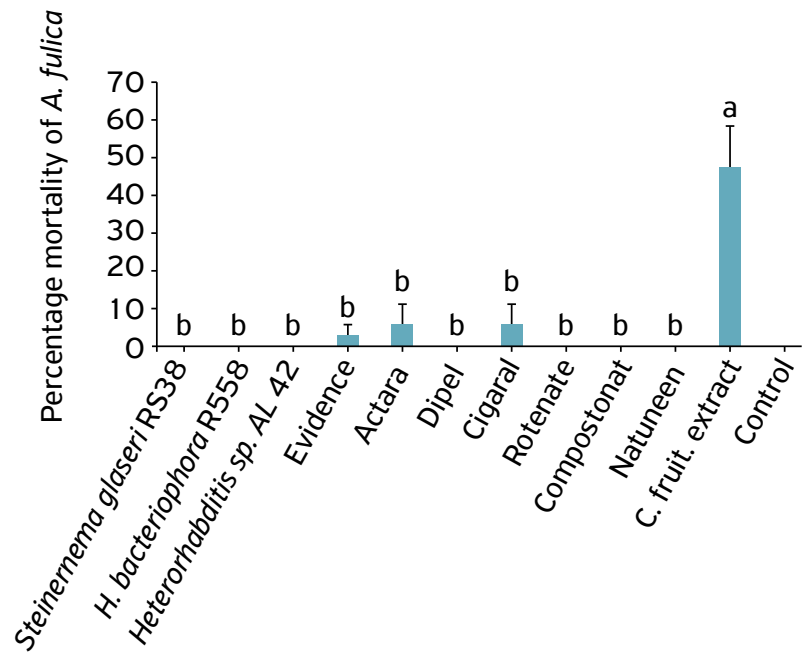

Figure 1. Percentage mortality ( \pm standard error) of Achatina fulica adults treated with entomopathogenic nematodes, commercial pesticides and commercial botanical extracts and alcoholics (Tukey $\leq$ 0.05).
Evidence, Dipel, Steinernema glaseri RS38, Heterorhabditis bacteriophora RS58, Heterorhabditis sp. AL42, Natuneem, Rotenat and Compostonat (Fig. 1).

Values lower than the ones found in the present work were observed in literature by some authors. MATA; MATA (2012) observed $8.33 \%$ of mortality of adult $A$. fulica 24 hours after application of pesticides Lesmax and Metarex, inside the plastic vessels containing soil and food (lettuce) at the laboratory. MORAES et al. (2013) obtained adult mortality of A. fulica for 15 days for the application of aqueous extracts:

- 25\%: Ruta graveolens L.;

- $\quad 16.66 \%$ : Baccharis dracunculifolia De Candole;

- $\quad 8.33 \%$ : Arnica chamissonis Less, at the concentration of $10 \%(\mathrm{w} / \mathrm{v})$.

Moreover, biocides derived from plants are generally more specific for the target organisms, resulting on lesser wastes and environmental risks, since the synthesis is often associated with defense mechanisms of plants against natural enemies.

Higher values were found by CARVALHO (2012) with $100 \%$ mortality percentage (5\% copper sulfate), $90 \%$ (semi-hydrated lime 10\%), 65\% (5\% semi-hydrated lime) and 50\% (semi-pure hydrated lime) for adults of $A$. fulica after application in the laboratory. Although not belonging to the same family of A. fulica, the gastropod Oncomelania hupensis (Gredler) (Littorinimorpha: Pomatiopsidae) showed $45 \%$ mortality after application of 100 of $S$. glaseri $\mathrm{IJs}$ per $\mathrm{cm}^{2}$ in pots in the ground surface, higher than the one found in this study (LI et al., 1986).

After application of the alcoholic extract of $C$. frutescens, all adults died exposed the radula, an anatomical structure that is used by mollusks for feeding, sometimes compared to a tongue. $A$. fulica produces a mucus glycoprotein substance comprises a mixture of components from various glands. This fluid is viscoelastic, resulting of the mixture secretion of various glands, and has various functions, such as particle transport vehicle of ciliary surface, products of secretion of water and electrolytes transferred through the epidermis and assists in locomotion (SÍRIO, 2005). According NAKAMOTO; CZERNUSZEWICZ (1993), evaluating the mucus secreted by $A$. fulica and Achatina achatina, verified carbon chains (proteins), carbohydrates and lipids. LORENZI; MARTINS (2008), comparing the mucus of $A$. fulica and $A$. achatina, observed low spectral variations to those relating tracks to glycoproteins groups and carbohydrates, with total sugar content of $3,07 \mathrm{mg} / \mathrm{mL}$ to $A$. monochromatic, with superiority significant of $1,13 \mathrm{mg} / \mathrm{mL}$ to $A$. fulica.

\section{Assessment of alcoholic extracts and oil of Capsicum frutescens on eggs of Achatina fulica}

In the treatment with the ENP Heterorhabditis sp. AL39, there was a higher percentage of hatching (100\%) similar 
with the control, and in the treatments with oil and alcoholic extract the control ( $0 \%$ of hatching) of snail eggs occured (Fig. 2). Thus, these results indicated the presence of toxicity and potential as indicated by GUSMAN et al. (2014) after exposure A. fulica adults to aqueous extracts of flower buds of Syzygium aromaticum (L.) at the concentration of $100 \%$. ORJALA et al. (1993) also described molluscicidal activity on Biomphalaria glabrata of compound (chromene-methyl-8-hydroxy-2,2-dimethyl-2H-chromene-6-carboxylate) isolated from Piper aduncum.

It was observed that, after the pepper extract application, adults, in order to perpetuate the species, put eggs far above its normal activity. These results are of great importance, for the early control of this pest in its long cycle, reducing much of the potential damage of this pest.

\section{Determination of concentration and lethal time of alcoholic extract of Capsicum frutescens on Achatina fulica in the laboratory}

The result of this study showed that the concentration of $5 \%$ was the one that caused the death of the young snails. In turn, the concentration of $10 \%$ was the one that caused statistically similar mortality at the concentration of $20 \%$, the latter being not recommended for its ability to cause greater discomfort to the applicator and the plant may cause toxicity. Furthermore, the target crop is lettuce, considering part of the plant is consumed fresh, corroborating the use of the product in a lower concentration of effective control, in this case $10 \%$ (Fig. 3). Lower data was obtained by GUSMAN et al. (2014), with $60 \%$ mortality of $A$. fulica adults in the maximum concentration of $100 \%$ compared to control, although there was no statistical difference between

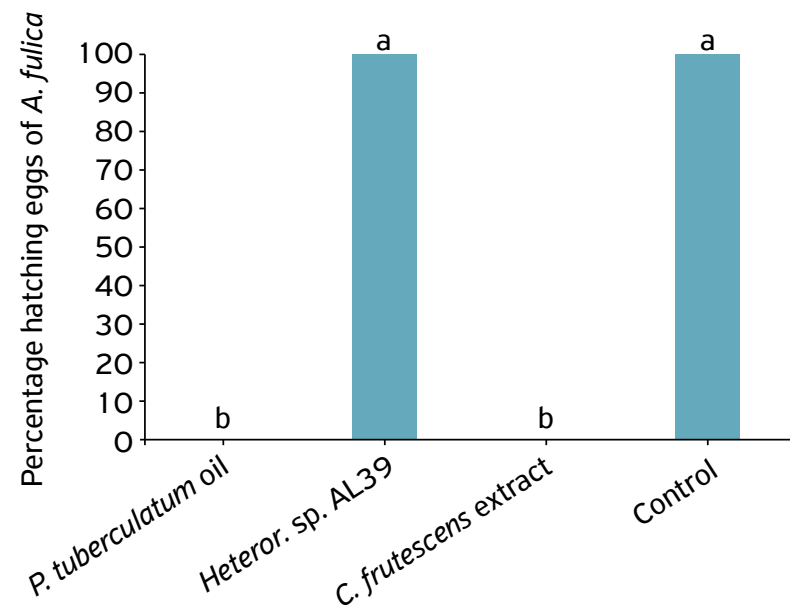

Figure 2. Percentage ( \pm standard error) hatching eggs of Achatina fulica treated with Heterorhabditis sp. AL39, alcoholic extract and oil of Capsicum frutescens and Piper tuberculatum. treatments after 24 days of aqueous extract of $S$. aromaticum experiment in the laboratory.

In order to know about the lethal time (LT) of $C$. frutescens on young and adults of $A$. fulica, significant mortality was observed in the first 24 hours and at lower concentration (15\%) (Fig. 4). Importantly, the concentration used in this bioassay was different. Better concentration determined for the lethal concentration (LC) in the previous bioassay was deliberate, because the LT may be a function of the applied concentration, having been used to intermediate concentration (15\%), compared to 10 and $20 \%$ concentrations (which were statistically the same in the previous test). Subsequently, however, new bioassays must be performed in order to adjust the LC versus LT, seeking to determine the optimum point between these two factors.

One of the main characteristics that favor the use of molluscicides natural products is their biodegradability and

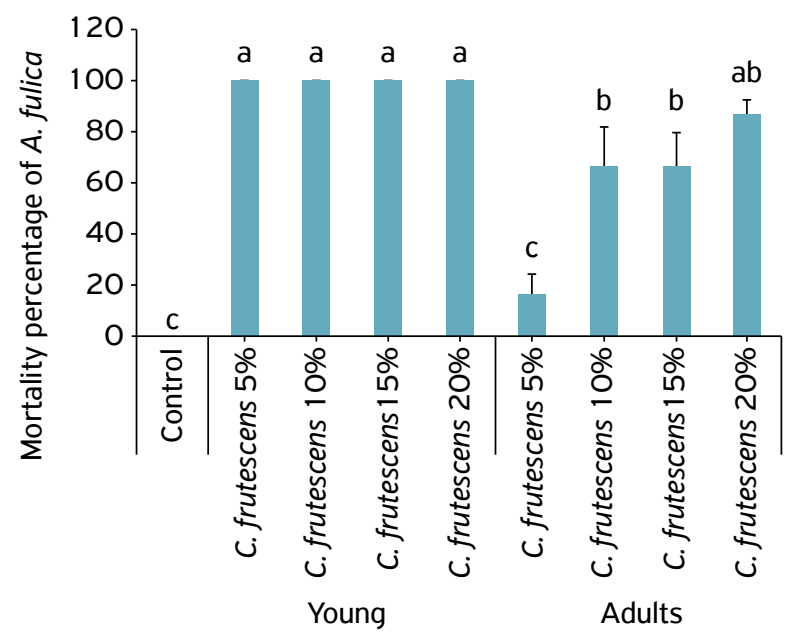

Figure 3. Mortality percentage ( \pm standard error) of young and adults of Achatina fulica treated with alcoholic extract of Capsicum frutescens in concentrations of 5, 10, 15 and 20\% (Tukey $\leq$ 0.05).

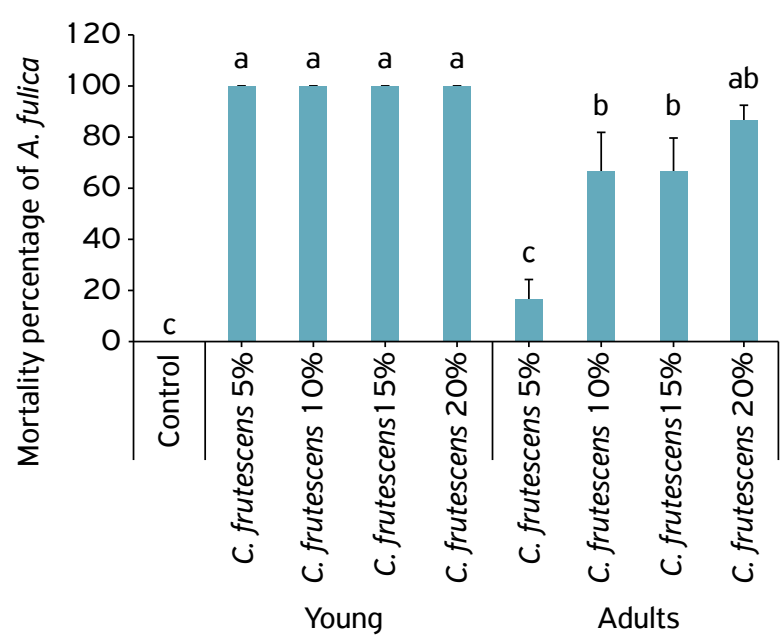

Figure 4. Mortality ( \pm standard error) of Achatina fulica in two periods of exposure to alcoholic extract of Capsicum frutescens. 
low toxicity to biota. In the current view of the control of the intermediate host, the use of substances of vegetable origin, mainly of native plants of the region, is well accepted by the populations of endemic areas where traditional medicine already employs plant species. Indeed, the study of molluscicides plant substances practically is restricted to species of aquatic molluscs, but may be an important alternative for the control of terrestrial molluscs (SÁ BARRETO et al., 2007). Besides the allelopathic potential, it was found that the aqueous extracts of flower buds of clove India did not significantly affect the hatching of eggs of A. fulica, however the percentage of survival and the final mass of the mollusk were significantly affected with increasing concentrations of the extracts used (GUSMAN et al., 2014).

In contrast to that obtained in this study, CRIGNIS (2011) observed that after 96 hours exposed to latex of Euphorbia milii Des Moul. var. splendens (Malpighiales: Euphorbiaceae), at the concentration of $7.50 \mathrm{~g}$ per L, caused $100 \%$ mortality of $A$. fulica.

Likewise, the latex species of the family Euphorbiaceae have terpenes with molluscicidal activity (100\% mortality on B. glabrata) (SCHALL et al., 1998).

\section{Determining the concentration of proteins in lipase activity and enzymatic activity of acetylcholinesterase and butyrylcholinesterase}

The lipase activity was $0.15167,0.008467,0.004533$ and $0.0042 \mu \mathrm{g}$ in all tissues, stomach, intestine, liver and ganglia, respectively, although there was no statistical difference between the protein concentrations (Fig. 5). These studies corroborated with FERRERI (1958a; 1958b) and FERRERI; DUCATO (1959), who observed the presence of lipases and esterases in gastropods, by the histochemistry of the epithelium of the

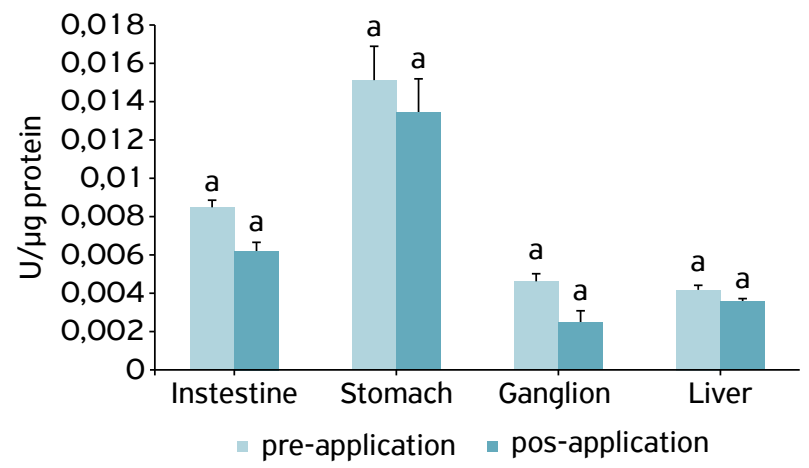

Figure 5. Evaluation of lipase activity in tissues (intestine, stomach, liver and ganglia) Achatina fulica depending on the concentration of protein in the protein extract of tissues before and after exposure to the alcoholic extract of Capsicum frutescens at the concentration of $10 \%$ (Tukey, $\mathrm{p} \leq 0.05$ ). digestive tract of Murex trunculus (Hexaplex trunculus) (Linnaeus, 1758) (Neogastropoda, Muricidae), Planorbis corneus (Linnaeus, 1758) (Basommatophora, Planorbidae), reflecting the overall composition of the diet (YONGE, 1937). Although the present study did not use the same enzyme, lipase activity of glutathione S-transferase (GST) A. fulica in liver was determined by CRIGNIS (2011) after exposure to latex concentration of E. milii (3.75 g per L), obtaining maximum activity of $2 \mathrm{U}$ per $\mathrm{mg}$ of this protein, considered superior to that one found in this work. SMINIA (1972) found that granular cell membrane of connective tissue Lymnaea stagna (Linnaeus, 1758) (Basommatophora, Lymnaeidae) and the nerve ganglia are responsible for secreting two protein factors (dopamine and octopamine) participating in the defense responses authority, indicating the presence of the protein content in these cells.

The lipase activity was higher in stomach than in the intestine, liver, ganglion or after exposure to the alcoholic extract of C. frutescens at $10 \%$ concentration, although no statistical difference between the protein concentrations was seen (Fig. 5). Reduction in the amount of protein concentration significantly decreased the lipase activity throughout the digestive tract of A. fulica, presenting higher and lower activity in the stomach and liver, respectively, after exposure to the alcoholic extract, despite no statistical difference. This situation probably indicates cell lysis and probable action of lipase. The analysis of the possible effects of applying molluscicide in lipase activity points out that the protein concentration (lipase) had a negative effect on enzyme production. No studies in the literature were found with the same purpose and the same methodology for analyzing protein in order to make a comparison.

Changes in the metabolism of carbohydrates and protein in snails in response to parasitism, starve, population density and photoperiod were observed (LUSTRINO et al., 2010). Nevertheless, there are few studies on changes in lipid metabolism (GARCIA; PINHEIRO, 2007).

Among the environmental factors that may influence the metabolism of snails, some authors have shown that photoperiod influences the sexual maturation, metabolism egg laying and carbohydrates, particularly glycogen and galactogen (WIJSMAN, 1989). In freshwater snail Lymnaea stagnalis, the photoperiod exerts an influence on the neuronal control of the cells of the lateral lobes of the cerebral ganglia (VAN MINNEN; REICHELT, 1980). But there is no information in the literature about the influence of this factor on the metabolism of lipids (triglycerides and cholesterol) of molluscs (LUSTRINO et al., 2010). Lipids have many functions in biological, energetic and structural systems (LUSTRINO et al., 2010). In snails, it was identified that the lipids are involved in survival in saline stress conditions, such as food restriction in long period, parasitism, depletion of carbohydrate and lipids stores, besides the different types of alterations lipids (BANDSTRA et al., 2006). They are structural components of biological membranes, and changes in the number and composition of these lipids may occur when 
changes in the metabolic state of snails occurr in response to stress factors (STUART et al., 1998a; 1998b).

Thus, environmental factors and the metabolism of this snail are points that require further study, since these changes in physiological pattern can give us information on distribution, survival and reproduction (LUSTRINO et al., 2010). The influence of photophases $(0,6,12,18$ and 24 hours) of the number of triglycerides total cholesterol was measured in the hemolymph of A. fulica (LUSTRINO et al., 2010). According to these authors, photophases between 6 and 18 hours are not able to induce significant changes in the content of cholesterol in the hemolymph of $A$. fulica. But, if it is assumed that there is the elimination of cholesterol molecules in cell membranes, this factor will lead to increased membrane fluidity, thereby causing increase in the rate of metabolic processes involving membrane proteins, such as those who work in the electron transport chain in mitochondria, even changing the permeability of the cell (NARAYANAN; VENKATESWARARA, 1980). According to LUSTRINO et al. (2010), it was observed in snails exposed during 24 hours of photoperiod, similar to that reported by THOMPSON; LEE (1986), to free glucose level in the hemolymph of molluscs, even parasitism and hunger situations, that were maintained at constant levels. Furthermore, the metabolism of triglycerides in A. fulica is more influenced by changes in photoperiod than the cholesterol metabolism. A negative relationship is maintained between the triglyceride content in the hemolymph and the different light regimes $(0,6,12,18$ and 24 hours), with lower triglyceride mobilization in shorter photophases (LUSTRINO et al., 2010). Moreover, it has been shown that the metabolism of triglycerides in $A$. fulica appears to be regulated by photoperiod in a more sensitive manner.

Acid phosphatase intracellular digestive system of $D$. reticulatum, which is found in primary lysosomes, has been influenced after treatment with molluscicidal. The activity of this enzyme has been shown to be completely inhibited after treatment with choethocarb and strongly reduced after being treated with methiocarb and metaldehyde (TRIEBSKORN, 1991). KELA; BOWEN (1995) observed reduction, but not the complete inhibition, of the acid phosphatase in the digestive gland of $L$. stagnalis, after treatment with natural molluscicide. VAN WEEL (1959) demonstrated that the midgut gland of gastropods produces carbohydrases, proteases (including extracellular peptidases and dipeptidases) and esterases, however the amount appears to depend on natural diet and the amount of food available.

VAN WELL (1960) observed that the enzyme production did not show a fit for a change in diet. The snails produce more protease when fed on starch than those who were fed on protein (MONRO, 1967). This is consistent with the biochemical observations of THIRLWELL et al. (1963) comparing the digestive juices of gastropods Helix pomatia (carnivora) and $A$. fulica (herbivora) when fed on lettuce.

The levels of hydrolytic enzymes in Achatina have been similar to the Helix. Differences occur primarily in the amount and distribution of both digestive enzymes and those associated with cellular metabolism (alkaline and acid phosphatase). In general, gastropods present throughout the digestive tract, the activity of alkaline phosphatase (MONRO, 1967) with high activity over basal membrane and intestinal muscles.

The specific activity of the enzyme $\mathrm{AChE}$ and $\mathrm{BuChE}$ was $0.1621 \mathrm{mg} / \mathrm{mL} 0.0331 \mathrm{mg} / \mathrm{mL}$ in the ganglion and $0 \mathrm{mg} /$ $\mathrm{mL} 0.0054 \mathrm{mg} / \mathrm{mL}$ in the liver of $A$. fulica, respectively prior to exposure to alcoholic extract of $C$. frutescens. There were predominance and no activity of $\mathrm{AChE}$ in the ganglion and liver, respectively, and low enzymatic activity of $\mathrm{BuChE}$ in these two bodies prior to exposure of $A$. fulica to the alcoholic extract, although there were not statistical differences (Fig. 6).

ZANCAN et al. (1994) demonstrated immunohistochemically the enzymatic activity of AChE activity in the central nervous system (CNS) of Megalobulimus abbreviatus (Pulmonata, Stylommatophora) (Bequaert, 1948), present in cortical neuronal layer and neuropil of nodes commissures, connective and nerve, with a stronger neural positive reaction occurring on the pedals and oral nodes and intense throughout the neuropil of the pedal ganglia. It was also confirmed its presence in nerve fibers of different diameters and sizes of nodes throughout the length of the dorsalis pedis muscles of the shellfish, and positive neurons distributed between epithelial cells in the epithelium of the foot snail (FACCIONIHENSER, 1999).

There is correlation of AChE activity in the pedis plexus of $M$. abbreviatus with probable presence of cholinergic circuits in pedal ganglia, suggesting that structures of this nerve plexus are also involved in these circuits, promoting mobility (FACCIONI-HENSER, 1999) and ganglia in the brain of the same species, suggesting its involvement in neuropeptide metabolism, with role in the modulation of eating behavior such gastropod (ZANCAN et al., 1997). ZAITSEVA et al. (2009)

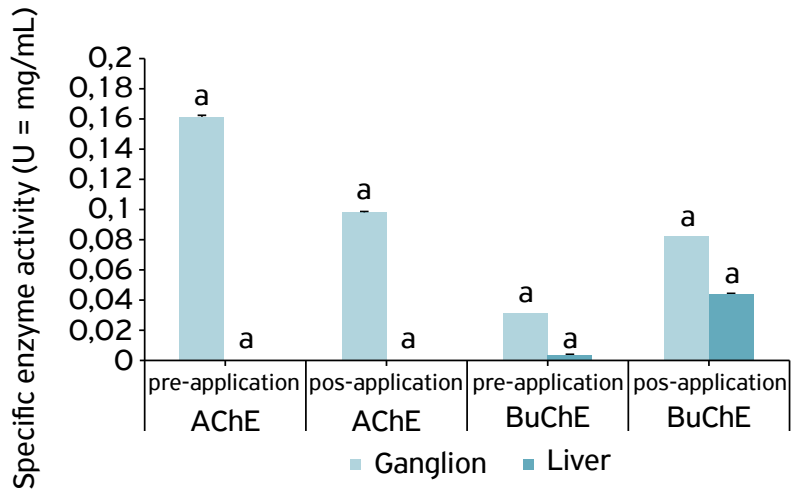

Figure 6. Evaluation of enzymatic activity of the acetylcholinesterase (AChE) and butyrylcholinesterase (BuChE) in tissues (liver and ganglia) of Achatina fulica depending on the concentration of protein extract of tissue proteins, before and after application of the alcoholic extract of Capsicum frutescens to $10 \%$ (Tukey, $\mathrm{p} \leq 0.05$ ). 
found similarities in the distribution of activity of cholinesterase (AChE) in the digestive tract of Littorina littorea (Linnaeus, 1758) (Neotaenioglossa, Littorinidae) and A. fulica. The nerve fibers of the granule cells of the digestive tract of $L$. littorea and A. fulica show cholinesterase activity (ChE), forming varicosities or terminations with high activity of this enzyme in these cells (ZAITSEVA; KUZNETSOVA, 2008).

Already FLYACHINSKAYA; ZAITSEVA (2007) found activities of cholinesterase (ChE) and nicotinamide adenine dinucleotide hydrogen phosphate diaphorase (NADPHd) in the nervous elements that innervate the mouth and pharynx of gastropods and larvae of bivalve molluscs. As reported by ELLIOTT; KEMENES (1992), the action of acetylcholine (AChE) varies depending on phylum of invertebrates, and in gastropods acts as a chemical mediator in motor synapses and interpreurais. It was observed that much higher concentrations of the pesticide Atrazine $(330 \mathrm{~g} / \mathrm{L})$ raised the maximum of $79 \%$ reduction in activity of various enzymes in the freshwater snails Biomphalaria alexandrina (Ehrenberg, 1831) (Basommatophora, Planorbidae), among them the AChE, which according MONRO (1967) adversely affects the immunity of snails (GRAYMORE et al., 2001).

There was predominance of $\mathrm{BuChE}$ in the muscle tissues (ganglia and liver), and total activity of this enzyme was positively affected by increasing the immune response of shellfish, independently, possibly in the presence and absence of $\mathrm{AChE}$ in ganglia and liver, respectively, after exposure to the alcoholic extract of $C$. frutescens. The specific enzyme activity of AChE and $\mathrm{BuChE}$ was $0,0989 \mathrm{mg} / \mathrm{mL} 0,0834 \mathrm{mg} / \mathrm{mL}$ and $0 \mathrm{mg} /$ $\mathrm{mL} 0,0453 \mathrm{mg} / \mathrm{mL}$ in ganglia and liver of A. fulica, respectively, after exposure to the alcoholic extract of $C$. frutescens. The enzymatic activity of AChE was low and absent in the ganglia and liver, respectively, due possibly to its inhibition after exposure $A$. fulica to the alcoholic extract of $C$. frutescens.

These data were also highlighted by some authors. SANCHEZ-HERNANDEZ (2007) describe the inhibition of AChE activity after exposure to organophosphate pesticides (OP) and carbamate (CB), considering one of the best examples demonstrated in toxicology. According to this author, this enzyme is responsible for the normal functioning of synapses in the central nervous system and autonomous, as well as in neuromuscular junctions. ALDRIDGE (1953) showed that the $\mathrm{AChE}$ belongs to a group of hydrolases classified as $\mathrm{B}$-esterase, which are inhibited by $\mathrm{OP}$ and $\mathrm{CB}$, calling them anti-ChE pesticides.

For decades, the inhibition of $\mathrm{AChE}$ has been the main biological response measured in organisms exposed to anti-ChE pesticides (SANCHEZ-HERNANDEZ, 2007). The measurement of inhibition of AChE has become an alternative biochemical analysis for the presence of anti-ChE and assess biodiversity and toxicity pesticides (SANCHEZ-HERNANDEZ, 2007). One of the challenges ecotoxicological B-esterases has been established by the relationship between the degree of inhibition of AChE in the brain and mortality body (SANCHEZ-HERNANDEZ, 2007). This relationship was established in reptiles (HALL; CLARK, 1982) and mammals (WALKER, 1998). However, each of these relationships could not be established for invertebrates, due to high variability in responses (FULTON; KEY, 2001). The activity of BuChE and carboxylesterase (CBE) and two ordinary B-esterase currently has gained increased interest in monitoring pollution by pesticides in the field (SANCHEZ-HERNANDEZ, 2007).

Finally, future lines of research are suggested to increase the understanding of B-esterase as pesticide tolerance on non-target organisms and their implications for the evaluation of anti-ChE agrochemical exposure in wildlife (SANCHEZHERNANDEZ, 2007). The same authors also report that can also occur BuChE inhibition activity of the compounds $(\mathrm{PO})$ and $(\mathrm{CB})$ in the same manner as for AChE (SANCHEZHERNANDEZ, 2007). Of the enzymological point of view, the activity of BuChE has been distinguished from the AChE activity mainly serving its substrate preference and specific inhibitors (SANCHEZ-HERNANDEZ, 2007). Historically, physiological functions have not been assigned to $\mathrm{BuChE}$, being a question of continuous gap (COOPER, 1994). However, $\mathrm{BuChE}$ appears to be involved in a wide variety of biological functions (SANCHEZ-HERNANDEZ, 2007). For example, there is strong evidence supporting the involvement of BuChE activity, along with $\mathrm{AChE}$, into neural transmission and differentiation (BRIMIJOIN, 2005).

\section{Efficiency of the alcoholic extract of Capsicum frutescens on Achatina fulica adults in the field}

The efficiency was statistically different with 84 and $40 \%$ of the snail mortality two days after exposure to the alcoholic extract of $C$. frutescens at concentrations of 10 and 5\%, respectively (Fig. 7). Similar results were observed by ARCHIBALD (1933) using aqueous extract of

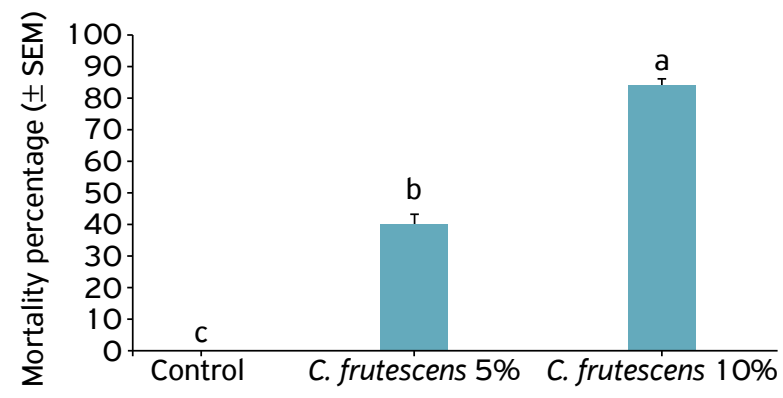

SEM: standard error of the mean.

Figure 7. Percentage mortality (mean \pm SEM) of adult of Achatina fulica two days after application of treatments (control and alcoholic extract of Capsicum frutescens) at 5 and $10 \%$ in lettuce (Lactuca sativa) on the field. 
fruit species Balanites aegyptiaca (L.) Delile and Balanites manghamii Sprague (Balanitaceae), causing mortality of snails Biomphalaria spp. and Bullinus spp., in Sudan (KLOOS; MCCULLOUGH, 1987). Likewise, the maritime Ambrosia maritima L. (Asteraceae) and Sapindus saponaria (L.) (Sapindaceae) were employed, with the same purpose (JURBERG et al., 1989; KLOOS; MCCULLOUGH, 1987).

\section{HIGHLIGHTS}

- The alcoholic extract of $C$. frutescens causes higher mortality of adult $A$. fulica;

- The alcoholic extract of $C$. frutescens in concentrations of 5 and $20 \%$ provides increased mortality of young people and adults of $A$. fulica, respectively, after 24 hours of application;

- The alcoholic extract of $C$. frutescens and $P$. tuberculatum oil can prevent the hatching of $A$. fulica;
- The lipase activity is present and in greater quantities in tissues, stomach, intestine, liver and ganglia of $A$. fulica, before and after exposure of the alcoholic extract of $C$. frutescens;

- The enzymatic activity of $\mathrm{BuChE}$ is present in the ganglia and liver of $A$. fulica, prior to exposure of the alcoholic extract of $C$. frutescens;

- The enzymatic activity of AChE is present only in the ganglion and absent in liver of A. fulica, prior to exposure of the alcoholic extract of $C$. frutescens;

- The enzymatic activity of AChE is low or inhibited and absent in the ganglia and liver of A. fulica, respectively, after exposure of the alcoholic extract of $C$. frutescens;

- The enzymatic activity of $\mathrm{BuChE}$ is high in the ganglion and liver $A$. fulica, after exposure of the alcoholic extract of $C$. frutescens;

- The concentration of $10 \%$ of the alcoholic extract of $C$. frutescens causes $84 \%$ mortality of adult $A$. fulica in lettuce in field conditions.

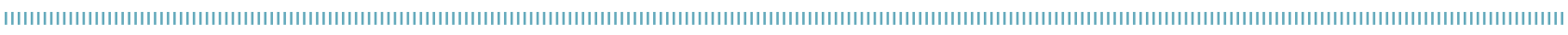
REFERENCES

ABOG, M.K.; RIVERA, J.J.; ESTACIO, S.C.W.; FIDELINO, J.S.; LAVILLA, O.J.Y.; PILAPIL, J.C.; TONGCO, M.D.C. Assessment of acute toxicity of thiamethoxam (Actara ${ }^{\circledR} 25 \mathrm{WG}$ ) to Achatina fulica and its potential ecological applications. Science Diliman, v.24, n.2, p.21-27, 2012.

ALDRIDGE, W.N. Serum esterases. I. Two types of esterase (A and B) hydrolysing p-nitrophenyl acetate, propionate and butyrate, and a method for their determination. Biochem Journal, v.53, n. 1 , p. $110-117,1953$.

ARCHIBALD, R.G. The use of the fruit of the tree Balanites aegyptiacanin the control of schiistosomiasis in the country-region Sudan. Transactions of the Royal Society of Tropical Medicine and Hygiene, v.27, n.2., p.207-210, 1933.

BACIC, A.; HARRIS, P.J.; STONE, B.A. Structure and function of plant cell walls. In: PREISS, J. (Ed) The biochemistry of plants. San Diego, CA: Academic Press, 1988. p.297-371.

BANDSTRA, S.R.; FRIED, B.; SHERMA, J. High performance thin chromatografic analysis of neutral lipids and phospholipids in Biomphalaria glabrata patently infected with Echinostoma caproni. Parasitology Research, v.99, n.4, p.414-418, 2006.

BARÇANTE, J.M.P.; BARÇANTE, T.A.; COSTA DIAS, S.R.; LIMA, W.S. Ocorrência de Achatina fulica Bowdich, 1822 (Mollusca: Gastropoda: Achatinoidea) no Estado de Minas Gerais. Boletim do Museu de Biologia Mello Leitão, v. 18, p.65-70, 2005.

BEZERRA NETO, F.; ROCHA, R.H.; ROCHA, R.C.; DE NEGREIROS, M.Z.; LEITÃO, M.M.; NUNES, G.H.; SOBRINHO, J.E.; QUEIROGA,
R.C. Sombreamento para produção de mudas de alface em alta temperatura e ampla luminosidade. Horticultura Brasileira, v.23, n. 1, p.133-137, 2005.

BOMFIM, T.C.B.; SOARES, G.L.G.; SALGADO, C.A.; KAPLAN, M.A.C. Toxidez seletiva do extrato etanólico bruto de Capsicum baccatum L. sobre Biomphalaria glabrata Say e Biomphalaria tenagophila Orbigny. Revista Brasileira de Plantas Medicinais, v.4, n.2, p.55-9, 2002.

BRADFORD, M.M. A rapid and sensitive method for the quantitation of microgram quantities of protein utilizing the principle of proteindye binding. Analytical Biochemistry, v.72, n.1-2, p.248-254, 1976.

BRIMIJOIN, S. Can cholinesterase inhibitors affect neural development? Environmental Toxicology and Pharmacology, v.19, n.3, p.429-432, 2005.

BROWN, M.; DAVIES, I.M.; MOFFAT, C.F.; REDSHAW, J.; CRAFT, J.A. Characteristic of choline esterases and their tissue and subcellular distribution in mussel (Mytilus edulis). Marine Environmental Research, v.57, n.3, p.155-169, 2004.

CARVALHO, R.A. Controle do caracol gigante africano (Achatina fulica Bowdich, 1822): ameaça ecológica, sanitária e agrícola. 2012. Available from: <http://www.mma.gov.br/estruturas/174/_ arquivos/174_0512200811 1625.pdf>.Accessed on:Nov. 12, 2015.

CHOI, S.J.; HWANG, J.M.; KIM, S.I. A colorimetric microplate assay method for high throughput analysis of lipase activity. Journal of Biochemistry and Molecular Biology, v.36, n.4, p.417-420, 2003. 
COOPER, J.R. Unsolved problems in the cholinergic nervous system. Journal of Neurochemistry, v.63, n.2, p.395-399, 1994.

CRIGNIS, R.N. Ação moluscicida do látex de Euphorbia milii Des. Moul. Var. Splens (Ursch \& leandri) em Achatina fulica (Bowdich, 1822) e seu efeito em biomarcadores ambientais. Vila Velha, Brazil, 2011 . Available from: <http://www.uvv.br/edital_doc/23.\%20 RENAN\%2ODE\%2ONARDI\%2ODE\%2OCRIGNIS.pdf>. Acessed on: Jan. 23, 2012.

DUN, G.S. The giant snail. Papua and New Guinea Agricultural Journal, v.18, p.213-215, 1967.

ELLIOTT, C.J.H.; KEMENES, G. Cholinergic interneurons in the feeding system of the pond snail Lymneal stagnalis. II. N1 interneurons make cholinergic synapses with feeding moto neurons. Philosophical Transactions of the Royal Society of London, v.336, n.1277, p.167-180, 1992.

EMBRAPA HORTALIÇAS. Hortaliças em revista: Produção de hortaliças \& crise hídrica. 2015. Available from: <https://www. embrapa.br/busca-de-noticias/-/noticia/2732320/producao-de-hortalicas--crise-hidrica>. Accessed on: Nov. 12, 2015.

Alface em números. 2013.

ESTON, M.R.; MENEZES, G.V.; ANTUNES, A.Z.; DOS SANTOS, A.S.; DOS SANTOS, A.M. Espécie invasora em unidade de conservação: Achatina fulica (Bowdich, 1822) no Parque Estadual Carlos Botelho, Sete Barras, SP, Brasil. Revista do Instituto Florestal de São Paulo, v. 18, p.173-179, 2006.

FACCIONI-HENSER, M.C. Aspectos histofisiológicos da musculatura e do plexo pedioso do caracol pulmonado Megalobulimus oblongus. 1999. 284f. Thesis (Doutorado em Ciências Biológicas - Fisiologia) Universidade Federal do Rio Grande do Sul, Porto Alegre, 1999.

FERRERI, E. L'attivitá lipasica dell'epitelio intestinale di Helix pomatia. Nota II. Bollettino Societa Italiana Biologia Sperimentale, v.34, p.379-382, 1958a.

Ricerche biochimiche ed histochimiche sul"attivitá lipasica dell' epitelio intestinale di Helix pomatia. Zeitschrift fur vergleichenden Physiologie, v.41, p.373-389, 1958b.

FERRERI, E.; DUCATO, L. Vergleichende biochemische und histochemische Untersuchungen iiberdie lipolytische Tatigkeit des Darmkanalepithelúims von Planorbis corneus L. und Murex trunculus L. Zeitschrift fur Zellforschung und mikroskopische Anatomie, v.51, p.65-77, 1959.

FISCHER, M.L.; COLLEY, E. Espécies invasoras em reservas naturais: caracterização da população de Achatina fulica Bowdich, 1822 (Molusca- Achatinidae) na ilha Rasa, Guaraqueçaba, Paraná, Brasil. Biota Neotropica, v.5, n. 1, p.127-144, 2005.

FISCHER, M.L.; COLLEY, E. Diagnóstico da ocorrência do caramujo gigante africano Achatina fulica Bowdich, 1822 na APA de Guaraqueçaba. Estudos de Biologia, v.26, n.54, p.43-50, 2004

FISCHER, M.L.; ZANATTA, A.A.; ADAMI, E.R. Um olhar da bioética para a zooterapia. Revista Latinoamericana de Bioética, v.16, n. 1, p.174-197, 2016. http://dx.doi.org/10.18359/rlbi.1460
FLORKIN, M.; LOZET, F.R. Origine bacterienne de la cellulase du contenu intestinal de 1 'escargot. Archives Internationales de Physiologie et de biochimie, v.57, p.201-207, 1949.

FLYACHINSKAYA, L.P.; ZAITSEVA, O.V. Distribution of NADPH Diaphorase and Acetylcholinesterase Activity in Developing Nervous System at the Veliger Stage in Myaarenaria and Dendronotus fron dosus, Materialy Simpoziuma s mezhdunar. Uchastiem "Kletochnye, molekulyarnye i evolyutsionnye as pekty morfogeneza”. In: Proceedings of the Symposium Internat. Particip. "Cellular, Molecular and Evolutionary Aspects of Morphogenesis. Moscow, 2007, p.161-163.

FOURNIER, D.; KARCH, F.; BRIDE, J.M.; HALL, L.M.; BERGÉ I.B.; SPIERER, P. Drosophila melanogaster acetylcholinesterase gene, structure evolution and mutations. Journal of Molecular Biology, v.210, n.1, p.15-22, 1989.

FULTON, M.H.; KEY, P.B. Acetylcholinesterase inhibition in estrearine fish and invertebrates as an indicator of organophosphorus insecticide exposure and effects. Environmental Toxicology and Chemistry, v.20, p.37-45, 2001.

GARCIA, T.A.; PINHEIRO, J. The photoperiod may modulate the carbohydrate metabolism of Bradybaena similaris (Férrussac, 1821 ) (Mollusca, Bradybaenidae). Revista Brasileira de Zoociências, v.9, n. 1, p.7-12, 2007.

GERLACH, J. Conturbatia, a new genus of Streptaxidae (Mollusca, Gastropoda, Pulmonata) Mitteilungen aus dem Museum für Naturkunde in Berlin. Zoologische Reihe, v.77, p.297-302, 2001.

GRAYMORE, M.; STAGNITTI, F.; ALLINSON, G. Impacts of atrazine in aquatic ecosystems. Environment International, v.26, n.7-8, p.483-495, 2001.

GUSMAN, G.S.; VIEIRA, L.R.; VESTENA, S. Atividade alelopática e moluscicida de Syzygium aromaticum (I.) Merr. \& Perry (Myrtaceae). Evidência, Joaçaba, v.14, n.2, p.113-128, 2014.

HALL, R.J.; CLARK, D.R. Responses of the iguanid lizard Anolis carolinensis to four organophosphorus pesticides. Environmental Pollution, v.28, p.45-52, 1982.

HENDERSON, N.T.; FARNSWORTH, N.; MYERS, T. Biochemistry of recognized molluscicidal compounds of plant origin. In: MOTT, K.E. (Ed) Plant molluscicides. Chichester: John Wiley, 1987, p.109-130.

JBILO, C.F.; BARTELS, A.C.; CHATONNET, A.; TOUTANTI, J.P.; LOCKRIDGE, $O$. Tissue distribution of human acetylcholinesterase and butyrylcholinesterase messenger rna. Toxicon, v.32, n. 11 , p. $1445-1457,1994$.

JURBERG, P.; DE VASCONCELLOS, M.C.; MENDES, N.M. Plants used as molluscacides a critical view. Memórias do Instituto Oswaldo Cruz, v.84, p.76-83, 1989.

KELA, S.L.; BOWEN, I.D. The histopathological effect of Detarium microcarpum extract, a naturally occurring plant molluscicide, on the mid-gut and the digestive gland of Lymnala stagnalis. Cell Biology International, v. 19, p. 175-181, 1995.

KLOOS, H.; MCCULLOUGH, F.S. 1987. Plant with recognized molluscicidae activity. In: MOTT, K.E. (Ed) Plant molluscicides. Chichester: John Wiley, 1987, p.45-108. 
LI, P.S.; DENG, C.S.; ZHANG, S.G.; YANG, H.W. Preliminary tests on Steinernema glaseri infecting the mail, Oncomelania hupensis, an intermediate host of Schistosoma japonica. Chinese Journal of Biology Control, v.2, p.50-52, 1986.

LOPES, J.C.; RIBEIRO, L.G.; ARAÚJO, M.G.; BERALDO, M.R. Produção de alface com doses de lodo de esgoto. Horticultura Brasileira, v.23, p.143-147, 2005.

LORENZI, A.T.; MARTINS, M.F. Análise colorimétrica e espectroscópica do muco de caracóis terrestres Achatina sp alimentados com ração diferenciada. Revista Brasileira de Zootecnia, v.37, n.3, p.572-579, 2008.

LUSTRINO, D.; TUNHOLI-ALVES, V.M.; TUNHOLI, V.M.; MARASSI, M.P.; PINHEIRO, J. Lipids analysis in hemolymph of African giant Achatina fulica (Bowdich, 1822) exposed to different photoperiods. Brazilian Journal of Biology, v.70, n. 1, p.129-134, 2010.

MACHADO, A.B.M.; BRESCOVIT, A.D.; MIELKE, O.H.; CASAGRANDE, M.; SILVEIRA, F.A.; OHLWEILER, F.P.; ZEPPELINI, D.; MARIA, M.; WIELOCH, A.H. Panorama geral dos invertebrados terrestres ameaçados de extinção, v.1, p. 302-493. In: MACHADO, A.B.; DRUMMOND, G.M.; PAGLIA, A.P. (Ed.). Livro vermelho da fauna brasileira ameaçada de extinção. Brasília DF: MMA, 2008. 1420p.

MACK, A.; ROBITZKI, A. The key role of butyrylcholinesterase during neurogenesis and neural disorders: an antisense5 çbutyrylcholinesterase-DNA study. Progress in Neurobiology, v.60, p.607-628, 2000.

MADELLA, C.R.; AURICCHIO, P. Record of Achatina fulica Bowdich (Mollusca, Gastropoda) in the Cerrado-Caatinga ecotone in southern Piauí State, Brazil. Acta Biológica Paranaense, Curitiba, v.43, p.53-60, 2014.

MADHUMATHY, A.P.; AIVAZI, A.; VIJAYAN, V.A. Larvicidal efficacy of Capsicum annum against Anopheles stephensi and Culex quinquefasciatus. Journal of Vector Borne Diseases, v.44, n.3, p.223-226, 2007.

MASSOULIÉ, J.; BON, S. The molecular forms of cholinesterase and acetylcholinesterase in vertebrates. Annual Review of Neuroscience, v.5, p.57-106, 1982.

MATA, A.S.; MATA, A.C. Eficiência na utilização de de iscas granuladas no controle de caramujos-africanos (Achatina fulica) Bowdich, 1822. Engenharia Ambiental - Espírito Santo do Pinhal, v.9, n.3, p.223-232, 2012.

MONRO, R.E.; MADEN, B.E.H.; TRAUT, R.R. The mechanism of peptide bond formation in protein synthesis. In: SHUGAR, D. (Ed) Genetic Elements, Properties and Function. London: Academic Press, 1967. p.178-203.

MONTEIRO, P. Alagoas se torna auto-suficiente na produção de alface, coentro e cebolinha: cultura de hortaliças em Arapiraca gera faturamente regular aos produtores. Agência SEBRAE de Notícias, 2008. Available from: <http://www.agenciasebrae. com.br>. Accessed on: Jul. 222015.

MORAES, P.R.; SILVA, R.A.; SILVA, D.A.; BITTENCOURT, A.H. Potencial biocida de extratos aquosos de Ruta graveolens L., Baccharis dracunculifolia DC e Arnica chamissonis Less sobre indivíduos adultos de Achatina fulica. Revista Científica da Faminas, v.9, p.91-101, 2013.

NAIR, K.R. Two sarcophagid parasites of Phytophagous terrestrial snails in Mysore state, India. Technical Bulletin of the Common Wealth Institute of Biological Control, v. 10, p.113-121, 1968.

NAKAMOTO, K.; CZERNUSZEWICZ, R.S. Infrared spectroscopy. In: RIORDAN, J.F.; VALLEE, B.L. (Eds.). Methods in enzymology. New York: Academic Press, 1993. v.226. p.259-289.

NARAYANAN, R.; VENKATESWARARARO, P. Effect of xiphidiocercarial infections on oxidation of glycolytic and Krebs cycle intermediates in Lymnaea luteola (Mollusca). Journal of Invertebrate Pathology, v.36, n.1, p.21-24, 1980.

NASCIMENTO, G.G.; LOCATELLI, J.; FREITAS, P.C.; SILVA, G.L. Antibacterial activity of plant extracts and phytochemicals on antibiotic-resistant bactéria. Brazilian Journal of Microbiology, v.31, p.247-56, 2000.

NUNES, B. The use of cholinesterases in ecotoxicology. Reviews of Environmental Contamination and Toxicology, v.212, p.2959, 201 1. https://doi.org/10.1007/978-1-4419-8453-1_2

OLIVEIRA, J.C.; GONÇALVES, T.S.; MONTEIRO, P.R.; SARAIVA, I.O.; VASCONCELOS, H.C. Ocorrência de Achatina fulica (Mollusca: Pulmonata: Achatinidae) em três bairros da cidade de Macapá, Amapá. Biota Amazônia (Macapá), v.2, p.78-81, 2012.

ORJALA, J.; ERDELMEIER, C.A.; WRIGHT, A.D.; RALI, T.; STICHER, 0 . Two chromenes and a prenylated benzoic-acid derivative from Piper aduncum. Phytochemistry, v.34, p.813-818, 1993.

PEREIRA, J.P.; SOUZA, C.P.; MENDES, N.M. Propriedades moluscicidas da Euphorbia cotinifolia L. Revista Brasileira de Pesquisas Médicas e Biológicas, v. 11, p.345-51, 1978.

PRASAD, G.S.; SINGH, D.R.; SENANI, S.; MEDHI, R.P. Eco-friendly way to keep away pestiferous Giant African snail, Achatina fulica Bowdich from nursery. Global Invasive Species Current Science (Bangalore), v.87, p.1657-1659, 2004.

PROSSER, C.L.; VAN WEEL, P.B. Effect of diet on digestive enzymes in midgut gland of African Giant Snarl, Achatina fulica Fér. Physiological Zoology, v.31, p.171-178, 1958.

RAE, R.G.; VERDUN, C.; GREWAL, P.S.; ROBERTSON, J.F.; WILSON, M.J. Biological control of terrestrial molluscs using Phasmarhabditis hermaphrodita - progress and prospects. Pest Management Science, v.63, p. $1153-1164,2007$.

RAUT, S.K.; BARKER, G.M. Achatina fulica Bowdich and other Achatinidae as Pests in Tropical Agriculture. In: BARKER, G.M. (Ed). Molluscs as Crop Pests. New Zealand: CAB Publishing, 2002. p. 55-114.

RAUT, S.K.; CHOSE, K.C. Viability of sperm in two land snail, Achatina fulica Bowdich and Macrochlamys indica Godwin-Austen. The Velinger, v.21, p.486-487, 1978.

. Factors influencing gestation length in two land snail Achatina fulica and Macrochlamys indica. Malacological Review, v.13, p.33-36, 1980. 
RIBEIRO, V.L.S.; AVANCINI, C.; GONÇALVES, K.; TOIGO, E.; VON POSER, G. Acaricidal activity of Calea serrata (Asteraceae) on Boophilus microplus and Rhipicephalus sanguineus. Veterinary Parasitology, v.151, p.351-354, 2008.

ROSEN, B. Vergleichende Studien iiber die Proteinasen von Gastropoden und Decapoden Crustaceen. Zeitschrift für vergleichende Physiologie, v.24, p.602-612, 1937.

SÁ BARRETO, L.C.; CARVALHO, E.F.; CUNHA-FILHO, M.S.; FERREIRA, C.P.; XAVIER, H.S. Atividade moluscicida de extrato de aucubina de Vitex gardneriana Schauer (Verbenaceae) em embriões, 2007 da Biomphalaria glabrata. Latin American Journal of Pharmacy, v.26, p.339-432, 2007.

SALA, F.C.; COSTA, C.P. Retrospectiva e tendência da alfacicultura brasileira. Horticultura Brasileira, v.30, p. 187-194, 2012.

SALLAM, A.; EL-WAKEIL, N. Biological and Ecological studies on land snails and their control. In: SOLONESKI, S. (Ed) Integrated Pest Management and Pest Control - Current and Future Tactics. InTech, 2012.

SANCHEZ-HERNANDEZ, J.C. Ecotoxicological perspective of $B$-esterases in the assessment of pesticide contamination. In: PLATTENBERG, R.H. (Ed) Environmental pollution. New York: New Research Publishers, 2007. p.1-45.

SANTOS, A.B.; SILVA, T.F.; PAIVA, L.M.; SANTOS, A.C.; ALVESLIMA, E.A. Efeito fungitóxico do óleo de nim sobre Metarhizium anisopliae var. acridum e Metarhizium anisopliae var. anisopliae. Revista Caatinga, v.22, p.17-22, 2009.

SANTOS, R.H.; DA SILVA, F.; CASALI, V.W.; CONDE, A.R. Efeito residual da adubação com composto orgânico sobre o crescimento e produção de alface. Pesquisa Agropecuária Brasileira, v.36, p.1395-1398, 2001.

SCHALL, V.T.; DE VASCONCELLOS, M.C.; DE SOUZA, C.P.; BAPTISTA, D.F. The molluscicidal activity of crown of Christ (Euphorbia splendens var. hislopii) latex on snails acting as intermediate hosts of Schistosoma mansoni and Schistosoma haematobium. American Journal Tropical Medicine and Hygiene, v.58, n. 1, p.7-10, 1998.

SCHWEITZER, E.S. Regulated and constitutive secretion of distinct molecular forms of acetylcholinesterase from PC 12 cells. Journal of Cell Science, v.106, p.731-740, 1993.

SHERLEY, G. Invasive species in the Pacific: a technical review and draft regional strategy. Samoa: South Pacific Regional Environment Programme, 2000.

SILVA, R.N.; SILVA, J.M.; SILVA, W.C. Horticultores e agrotóxicos: estudo de caso no município de Arapiraca ( $\mathrm{AL}$ ). Revista IberoAmericana de Ciências Ambientais (Aquidabã), v.4, p.56-68, 2013.

SIMONE, L.R. Mollusca terrestres. In: BRANDÃO, R.F.; CANCELLO, E.M. (Eds) Invertebrados terrestres: biodiversidade do Estado de São Paulo, Brasil. São Paulo: FAPESP, 1999. p.3-8.

SÍRIO, O.J. Verificação da potencialização do efeito cicatrizante do muco de caracóis do gênero Achatina promovida por ração à base de confrei. 87p. Dissertation (Mestrado em Nutrição Animal) Universidade de São Paulo, Pirassununga, 2005.
SMINIA, T. Structure and function of blood and connective tissue cells of the fresh water pulmonate Lymnaea stagnalis studied by electron microscopy and enzyme histochemistry. Zeitschrift fur Zellforschung und mikroskopische Anatomie, v.130, n.4, p.497-526, 1972.

STUART, J.A.; GILLIS, T.E.; BALLANTYNE, J.S. Compositional correlates of metabolic depression in the mitochondrial membranes of estivating snails. American Journal of Physiology-Regulatory, Integrative and Comparative Physiology, v.44, n.6, p.19771982, 1998a.

Remodeling of phospholipid fatty acids in mitochondrial membranes of estivating snails. Lipids, v.33, n.8, p.787-793, 1998 b.

TALESA, V.; ROMANI, R.; ANTOGNELLI, C.; GIOVANNINI, E.; ROSI, $\mathrm{G}$. Soluble and membrane-bound acetylcholinesterases in Mytilus galloprovincialis (Pelecypoda: Filibranchia) from the northern Adriatic sea. Chemico-Biological Interact, v.134, p.151-166, 2001.

TAN, L.; GREWAL, P.S. Infection behavior of the rhabditid nematode Phasmarhabditis hermaphrodita to the grey garden slug Deroceras reticulatum. Journal of Parasitology, v.87, p.1349-1354, 2001.

TELES, H.M.; FONTES, L.R. Implicações da introdução e dispersão de Achatina fulica Bowdich, 1822 no Brasil. Boletim do Instituto Adolfo Lutz, v12, p.3-5, 2002.

TELES, H.M.S.; FONTES, L.R.; AMARAL, W. Pesquisa nacional de opinião pública sobre a espécie do caramujo Achatina fulica. Instituto Brasileiro de Helicicultura - IBH/CEDIC, p. 1-24, 2004.

THIENGO, S.C.; FARACO, F.A.; SALGADO, N.C.; COWIE, R.H.; FERNANDEZ, M.A. Rapid spread of an invasive snail in South America: the giant African snail, Achatina fulica, in Brasil. Biological Invasions, v.9, p.693-702, 2007.

THIRLWELL, M.P.; STRASDINE, G.A.; WHITAKER, D.R. A coinparison of hydrolase and lytic activities of the digestive juices of the Giant African Snail, Achatina fulica and Helix pomatia. Canadian Journal of Biochemistry and Physiology, v.41, p.1603-1610, 1963.

THOMAZINI, M.J. Seminário sobre segurança biológica na Amazônia. Rio Branco, Acre, Anais do Seminário sobre Segurança Biológica na Amazônia; I. Embrapa Acre, Documentos/Embrapa, Acre, 2008. 163p.

THOMPSON, S.N.; LEE, R.K. Comparison of starvation and infection by Schistosoma mansoni on tissue viability and the 31P NMR spectrum of Biomphalaria glabrata. Zeitschrift für Parasitenkunde, v.72, n.3, p.412-421, 1986.

TOMIYAMA, K.; MIYASHITA, K.; Variation of egg clutches in the Giant African snail, Achatina fulica (Ferussac) (Stylommatophora; Achatinidae). Venus, v.51, n.4, p.293-301, 1992.

TOMIYAMA, K.; NAKANE, M. Dispersal patterns of the giant African snail, Achatina fulica (Ferussac) (Stylommatophora: Achatinidae), equipped with a radiatransmitter. Journal of Molluscan Studies, v.3, p.315-322, 1993.

TOMIYAMA, K. Homing behavior of the giant African snail, Achatina fulica (Ferussac) (Gastropoda; Pulmonata). Journal of Ethiology, v.10, p.139-147, 1992. 
Courtship behaviour of the Giant African snail, Achatina fulica (Ferussac) (Stylommatophora; Achatinidae) in the field. Journal of Molluscan Studies, v.60, p.47-54, 1994.

TRIEBSKORN, K. 1991. The impact of molluscicides on enzyme activities in the hepatopancreas of Deroceras retiailatum (Muller). Malacologia, v.33, p.255-272.

TUNHOLI-ALVES, V.M.; TUNHOLI, V.M.; AMARAL, L.S.; MOTA, E.M.; MALDONADO JÚNIOR, A.; PINHEIRO, J.; GARCIA, J. Journal of Invertebrate Pathology, v.124, p.1-5, 2015.

VAN MINNEN, J.; REICHELT, D. Photoperiod-dependent neural control of the activity of the neurosecretory canopy cell in the lateral lobes of the cerebral ganglia of the freshwater pulmonate Lymnaea stagnalis (L.). Cell Tissue Research, v.208, n.3, p.457-465, 1980.

The effect of special diets on the digestion processes (enzyme production and resorption) in the african giant snail, Achatina fulica. Zeitschrift fiir vergleichende Physiologic, v.42, p.433-448, 1959.

VENETTE, R.C.; LARSON, M. Mini Risk Assessment Giant African Snail, Achatina fulica Bowdich (Gastropoda: Achatinidae). 2004. Available from: <http://www.aphis.usda.gov/plant_health/ plant_pest_info/pest_detection/downloads/pra/afulicapra.pdf]>. Accessed on: Oct. 062013.

WALKER, C.H. The use of biomarkers to measure the interactive effects of chemicals. Ecotoxicology and Environmental Safety, v.40, p.65-70, 1998.

WALKER, R.J.; HOLDEN-DYE, L. Commentary on the evolution of transmitters, receptors and ion. Channels in invertebrates.
Comparative Biochemistry and Physiology - Part A Molecular and Integrative Physiology, v.93, p.25-39, 1989.

WANG, X.; LIU, Z.; WANGA, W.; YAN, Z.; ZHANG, C.; WANG, W.; CHEN, L. Assessment of toxic effects of triclosan on the terrestrial snail (Achatina fulica). Chemosphere, v. 108, p.225-230, 2014.

WIJSMAN, T.C. Glycogen and galactogen in the albumen gland of the freshwater snail Lymnaea stagnalis: effects of egg laying photoperiod and starvation. Comparative Biochemistry and Physiology A, v.92, n. 1, p.53-59, 1989.

WOODRING, J.L.; KAYA, H.K. Steinernematidae and Heterorhabiditidae nematodes: a handbook of techniques soulhern cooperative. Arkansas: Arkansas Agricultural Experiment Station Falleteville, Séries Bulletin, 331, 1988.

YONGE, C.M. The biology of Aporrbais pes-pelicani (L.) and A. serresiana (Mich.). Journal of the Marine Biological Association UK, v.21, p.687-703, 1937.

ZAITSEVA, O.V.; KUZNETSOVAB, T.V.; MARKOSOVA, T.G. NADPH Diaphorase Activity in the Digestive System of Gastropod Molluscs Achatina fulica and Littorina littorea. Journal of Evolutionary Biochemistry and Physiology, v.45, n. 1, p.125-137, 2009.

ZANCAN, D.M.; NOBREGA, H.G.; SEVERINO, A.G.; ACHAVAL, $M$. Acetylcolinesterase distribution in the central nervous system of the Megalobulimus oblongus (Gastropoda, Pulmonata). Archives d'Anatomie, d'Histologie et d'Embryologie Normales et Expérimentales, v.75, p.75-86, 1994.

ZEWDIE, Y.; BOSLAND, P.W. Capsaicinoid profiles are not good chemotaxonomic indicators for Capsicum species. Biochemical Systematics and Ecology, v.29, p.161-169, 2001. 